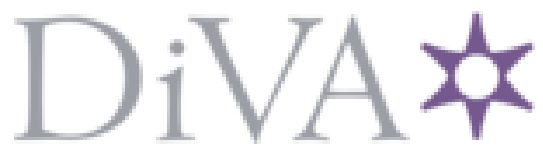

http://www.diva-portal.org

This is the published version of a paper published in Journal of Sustainable Tourism.

Citation for the original published paper (version of record):

Zhang, J. (2019)

Tourism and environmental subjectivities in the Anthropocene: observations from Niru Village, Southwest China

Journal of Sustainable Tourism, 27(4): 488-502

https://doi.org/10.108o/o9669582.2018.1435671

Access to the published version may require subscription.

N.B. When citing this work, cite the original published paper.

Permanent link to this version:

http://urn.kb.se/resolve?urn=urn:nbn:se:umu:diva-148852 


\section{Tourism and environmental subjectivities in the Anthropocene: observations from Niru Village, Southwest China}

\section{Jundan Zhang}

To cite this article: Jundan Zhang (2019) Tourism and environmental subjectivities in the Anthropocene: observations from Niru Village, Southwest China, Journal of Sustainable Tourism, 27:4, 488-502, DOI: 10.1080/09669582.2018.1435671

To link to this article: https://doi.org/10.1080/09669582.2018.1435671

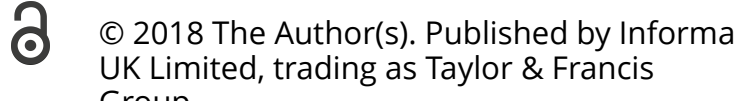
Group

曲 Published online: 26 Feb 2018.

Submit your article to this journal $\sqrt{2}$

山 Article views: 553

View Crossmark data $\nearrow$ 


\title{
Tourism and environmental subjectivities in the Anthropocene: observations from Niru Village, Southwest China
}

\author{
Jundan Zhang \\ Department of Geography and Economic History, Umeå University, Umeå, Sweden
}

\begin{abstract}
The increasingly popular notion of Anthropocene urges us to reflect and review the role of the human, the Anthropos, as part of the planet earth. In this context, tourism has been singled out as a global industry that is driven by neoliberal economic principles and is inevitably intertwined in the production of the Anthropocene. At the same time, tourism has been adopted also as part of environmental governance and management, aiming for a more sustainable economy. Based on the idea that ecotourism contributes to the discourse of "nature" (and Anthropocene) disruptively as well as productively in unsettling the normative ideas of "nature" and "culture", in this article I attempt to understand more specifically how ecotourism may enable individuals' subject formation in relation to the broader environmental discourse. Drawn on fieldwork in Niru Village, Shangri-La, Southwest China, I employ a political ecology approach and examine the ways individuals relate themselves to "nature", through a process of negotiation and exchange with others engaged in ecotourism activities. The tourism encounters in Niru Village, therefore are also embodied encounters of different environmental subjectivities.
\end{abstract}

\section{ARTICLE HISTORY}

Received 2 May 2017

Accepted 25 January 2018

\section{KEYWORDS}

Anthropocene; Shangri-La; tourism encounters; environmental subjectivities; political ecology

\section{Introduction}

In this paper I look at how, as recent studies discuss (Gren \& Huijbens, 2014, 2016; Huijbens \& Gren, 2016; Moore, 2015), the notion of Anthropocene may help us make sense of the Earth through tourism practices and development. Derived from the natural sciences, the notion of Anthropocene is proposed for naming the new geological epoch in which "the Anthropos", humanity, is the main operating force (Crutzen, 2002; Crutzen \& Stoermer, 2000; Zalasiewicz et al., 2011). Condensing all disparate environmental crises into a single word (Davies, 2016), the Anthropocene once again evokes familiar themes such as sustainability, conservation and resilience within the studies of sustainable tourism (Hall, 2016; Svensson, Sörlin, \& Wormbs, 2016). Immediate responses regarding the relationship between tourism and the Anthropocene are often directed at the most apparently relevant elements in the tourism industry, such as energy and resource consumption (Eijgelaar, Amelung, \& Peeters, 2016) and the ethical behaviours of tourists and tourism operators (Baruchello, 2016; Kristoffersen, Norum, \& Kramvig, 2016). What is more relevant, yet less discussed, is how the Anthropocene on local levels is shaping our perception, decision-making processes and actions in tourism studies and practices.

This article therefore draws attention to local villagers and tourists who took part in my 2013 ethnographic fieldwork in Niru Village, Shangri-La City, Southwest China. Remote from the global centres where discourses on the Anthropocene are forming, Niru Village nevertheless offers local accounts of

\section{CONTACT Jundan Zhang jundan.zhang@umu.se}


it in how the villagers show their awareness regarding recent natural disasters and environmental degradations. However, as I will discuss below, this awareness is illustrated through the villagers' increasing interactions with tourists and their other involvements in the local tourism development. I will then elaborate on individuals' ideas and attitudes towards "nature" and how they form certain sets of environmental subjectivities, or social formations, mediated through ecotourism practices. Fifty-three kilometres from the central town of Shangri-La, Niru villagers have historically depended on the forest resource and have developed a semi-farming, semi-grazing, structured economy; although, in recent years, this economy has taken a turn towards tourism. In contrast to the wellestablished ecotourism products in Shangri-La City (thanks to its name-changing strategy), such as Pudacuo National Park and Dukezong Old Town, Niru Village has struggled and finally come up with a niche with which to brand itself, as "Shangri-La's backyard" (xianggelila de houhuayuan) (Zhang \& Tucker, 2018). During the process of developing ecotourism products, individuals are brought together in Niru Village as tourists and hosts, who may articulate differently on the subject of "nature" yet are somehow able to exchange and negotiate these differences through their tourism encounters.

I have argued, from a poststructuralist political ecology perspective (Zhang, 2016b), that people as carriers of ideas and ideologies are crucial players in the hybridization of different regimes of "nature". This means that tourism (and tourism destinations) should always be viewed within a vibrant environmental discourse, since individuals constantly mingle and negotiate with their biological and social others through tourism products at tourism destinations (Zhang, 2016a). Bearing this in mind, in this article I see and use the notion of Anthropocene as further adding to the everexpanding forms of discourse on "nature", both deriving from and contributing to these discourses. In other words, I believe the significance of the term Anthropocene lies more in opening new ways of understanding and responding to the modern ecological catastrophe than in accurately defining the geological epoch.

Thus, this study seeks to contribute not simply to the growing literature on tourism and the Anthropocene, but more generally to the long-existing discussions on tourism and environmental discourse. This is done in three aspects. First, with the intention of bringing forward the individual perceptions of and engagements with the broader environmental discourses, I look at environmental subjectivities from a political ecology perspective. Environmental subjectivities address the formation process of how individuals construct and reconstruct a set of discursive relationships with "nature". Second, the focus on environmental subjectivities provides local contexts within which the metanarratives of environmental discourses, such as Anthropocene, operate. This will help us understand how new possibilities of subjectivities appear when people's livelihood and lifestyle are challenged in a context of large-scale modern practices and development. In the case of Niru Village, increasing social mobilization and the introduction of new conservation policies and technologies offer an opportunity for a re-examination of people's ideas about the role of "nature" that closely interrogates the binaries of nature/culture and Indigenous/modern. Finally, studying environmental subjectivities may shed light on new collaborations that emerge from individual encounters. This in turn will elucidate the diversity that has always existed and contributed to environmental discourses.

\section{Political ecology of tourism in the Anthropocene}

In Castree's (2014a, 2014b, 2014c) trio of Anthropocene papers, he presents a comprehensive picture of the concept's past, present and future. In a nutshell, Anthropocene was coined by Eugene Stoermer in the 1980s, and then gained prominence when Nobel Prize-winning atmospheric scientist Paul Crutzen proposed that, after the Holocene epoch, the Anthropocene is the new era, with humans being the predominant force shaping the Earth's surface (Crutzen, 2002; Crutzen \& Stoermer, 2000; Zalasiewicz et al., 2011). While the term remains to be verified within geological and environmental sciences, its symbolic charge and popular appeal have long since left behind 
the verification processes of natural science, and the term has gained increasing credence both within and outside academia. As Castree (2014a) notes, the term can be seen as "a new, more graphic way to frame an existing idea, namely, that of 'global environmental change' caused by human activities and extending in causes and effect beyond climate change" (p. 441). Purdy (2015) rightly points out that the term Anthropocene is similar to "the environment", which gained prominence in the 1960 s, and is a call to take responsibility for a changing planet (p. 4). In a sense, Anthropocene urges us to reflect on and review the role of the human, the Anthropos, as part of planet Earth, from local community policies to global industrial franchises. In this context, tourism has been singled out as a global industry that is driven by neoliberal economic principles and is inevitably intertwined in the making of the Anthropocene (Eijgelaar et al., 2016; Hall, 2016). At the same time, tourism has also been adopted as part of environmental governance and management, aiming for a more sustainable economy (there are many examples of this in the Journal of Sustainable Tourism). Haraway (2015) proposes that our job as world citizens is to "make the Anthropocene as short as possible and to cultivate with each other in every way imaginable epochs to come that can replenish refuge" (p. 160). What tourism can contribute in fulfilling this task is intriguing.

As mentioned above, recent works within tourism studies have begun to outline tourism's planetary impacts (Eijgelaar et al., 2016; Hall, 2016) and how an Anthropocene ethics can be mediated through nature-based tourism practices (Kristoffersen et al., 2016) and tourism destinations that provide different understandings of landscape (Svensson et al., 2016). To problematize the seemingly straightforward role tourism plays in the Anthropocene, several scholars have explored the question through different approaches in order to address the responsibilities tourism may take on in the proposed epoch. Jóhannesson, Ren, and Van Der Duim (2016) employ Actor Network Theory, regarding tourism encounters as being produced, and producing, within the complex and fragmented notion of the Earth. In a similar vein, Jönsson (2016) argues that the abstraction and generality of the idea of Anthropocene can be problematic when simply added as a background in tourism studies, as it is the particular processes in environmental transformations that tell stories about power relations and inequalities within tourism development. It is through a focus on the particularities that we, as tourism researchers, can address tourism's responsibilities in the Anthropocene and what comes after.

Following a line of argument similar to Jönsson (2016) and Jóhannesson et al. (2016), in this paper I employ political ecology to scrutinize some particular encounters among individuals and their environments, enabled by ecotourism, in Niru Village, Shangri-La, Southwest China. Political ecology frameworks have been used to conceptualize and contextualize tourism within the discourse of environment (Mostafanezhad, Norum, Shelton, \& Thompson-Carr, 2016; Nepal \& Saarinen, 2016; Stonich, 1998). Historically situated and place-based, political ecology frameworks are useful in examining relationships between and across actors at different scales within tourism practices, and can help us tackle the intricate dilemmas existing within sustainable tourism as an alternative form of development (Mostafanezhad et al., 2016). A growing body of literature investigates the position of nature-based tourism in green economies and green governmentality (Law, De Lacy, Lipman, \& Jiang, 2016; Reddy \& Wilkes, 2015). However, I have suggested that it is important to also recognize the poststructuralist elements in political ecology and to rethink ecotourism within the local-global and nature-culture dialectics (Zhang, 2016b); that is, to consider ecotourism as a constant hybridization of different regimes and ideologies of "nature" and to recognize tourism's contribution to the discourse of "nature" (and Anthropocene) as disruptive, but also productive, in unsettling the normative ideas of "nature" and "culture" (Zhang, 2016b). One way to understand how this process is realized is to examine the ways individuals relate to "nature", through negotiation and exchange with others in tourism activities. Therefore, in this paper, I specifically explore the process of negotiating, and interaction between, the assemblages of ideas, attitudes and actions, which, in political ecology studies, is contained within the concept of environmental subjectivity. 


\section{Tourism and environmental subjects in Niru Village, Shangri-La City, Southwest China}

Here, my analysis is based on stories from a village located in the rural area of Shangri-La City, Southwest China. Since its name change (and tourism branding) in 2001, Shangri-La City has attracted a great deal of attention from tourists and researchers alike. Since the establishment of the People's Republic, Shangri-La and its surrounding regions, together with other peripherals, have acted as raw material suppliers for infrastructure development in the coastal areas. The exploitation of natural resources led to increasing numbers of natural disasters and eventually a devastating flood of the Yangtze River in 1998, claiming thousands of people's lives and causing tremendous economic loss (Zhao \& Shao, 2002). Following this was a logging ban by the central government, and a series of policies and plans to install a "green economy", of which tourism is a crucial part, to provide substitute income (Mu, Yang, \& Zhou, 2007). Now, millions of tourists visit in order to admire and worship the alpine grassland, Snow Mountains and grand gorges.

The historical background of (eco)tourism development in Shangri-La, in combination with a topdown approach of conservation, reflects what Xu, Cui, Sofield, and Li (2014) maintain in their paper, that ecotourism development in China is closely associated with the country's progression towards modernity and is strongly influenced by global environmental movements. In this context, ecotourism products are often packaged with introduced Western forms of conservation, such as national parks, which also introduces a dilemma as it is weaved in the building of an "ecological state" in China (Zinda, 2014). It has been increasingly recognized that the current ecotourism management model in China is based on Western ideas of human-nature relations and could be more efficient if it integrated traditional Chinese culture, or sacred ecological knowledge (that is, beyond ethnic Han Chinese), into conservational tools (Grumbine \& Xu, 2011; Xu et al., 2005, 2014). Such discussions are again part of the environmental discourses in which a hybridization of different regimes of "nature" is constantly happening. It is important to remember here that economic and ecological transformations are carried out through tourism.

Located within this context of tourism development, Niru Village caught my attention during my 2013 fieldwork in Pudacuo National Park in Shangri-La. As a consequence of a shift from the logging industry towards a tourism-oriented economy, Pudacuo National Park, a 50-minute drive from the central town of Shangri-La, was established in 2007 as the first national park in Mainland China. Because of its geographic proximity and the ecological compensation agreement the park made with nearby villages, some villagers from Niru Village were given jobs as bus drivers and bus interpreters in Pudacuo. I got to know one of the bus drivers, and he and his family introduced me to the village. While Niru Village has also experienced the ecological and economic transformation as a general result of China's environmental governance, the desire for and interest in tourism development have been greatly influenced by the opening of Pudacuo National Park. First and foremost, the park demonstrates a shift in the regional economy, which makes nearby villages like Niru Village acutely aware of the possibilities offered by tourism. Second, the economic success of the park affects the incomes of the Niru villagers in both direct and indirect ways; and as I will discuss later, this generates both hope and frustration in terms of how much the villagers can participate in their own "tourism dream" (Zhang \& Tucker, in press). Last but not least, combining a protected area and ecotourism, Pudacuo National Park exemplifies that "nature" can make money in a less destructive way. Together with other events, this brings the metanarrative of environmental changes closer to local villagers' everyday life.

Fifty-three kilometres from the central town of Shangri-La (Compilation Committee of Luoji Township Annals, 2007), Niru Village covers $406 \mathrm{~km}^{2}$; however, only $0.16 \%$ of this area is arable (Lu, 2005). All villagers in Niru Village are ethnic Tibetans, making it the only solely Tibetan-populated village in Luoji town, and the largest Tibetan-populated village in Shangri-La. Six hundred and forty-three villagers live in 108 households in three village groups, namely Nizhong, Baizhong and Pula (Compilation Committee of Luoji Township Annals, 2007). Historically reliant on the forest resource, farming and husbandry, the villagers in Niru Village have built their knowledge, beliefs and everyday life 
around their interconnections with the environment. As mentioned above, the recent tourism development, such as Pudacuo National Park in Shangri-La, has nevertheless permeated Niru Village; however, it is a process not without its hitches.

While the tourism in Shangri-La has developed rather dramatically (Hillman, 2003; Kolas, 2008), Niru Village struggles to attract tourists even while packaging its remoteness and wilderness with other types of place-branding. Before 2002, there was no road to the village. The inaccessibility, and thus the undisturbed originality, caused the village to be selected by the regional government in order to showcase the universal value of an ecological environment to the UNESCO investigation team in the process of applying for the region to be named a natural World Heritage Site (Yang, 2012). The UNESCO team's visit to Niru Village played a major role in the successful listing of the Three Parallel Rivers of Yunnan-Protected Areas, but the tourism development promised in the local government's rhetoric has not been realized to the extent of the villagers' anticipation (Zhang \& Tucker, in press). Indeed, the villagers were not only disappointed by the fact that fewer tourists than expected travel to Niru Village, but were also confused about whether or not the application for the UNESCO listing had been approved. Zhang and Tucker (2017) argue that the UNESCO outstanding universal values criteria have singularly prioritized the physical and biological aspects of the local environment, which is a dualistic view of "nature" the local villagers do not share. Consequently, this dualism influenced the selection process and the construction of identities at the local level. Although Niru villagers were proud that their village was selected for the UNESCO visit, thus allowing them to identify themselves as "Niru Tibetans", they soon realized that UNESCO does not see "culture" and "intangible heritage" as part of the celebrated universal values of natural heritage. As I observed in my fieldwork, identity construction is thus shifted in an environmental direction, through which the local villagers can negotiate with the dominant discourse on "nature" as illustrated in the outstanding universal values.

The very move of changing the direction of self-identification, together with the will to negotiate with the broader environmental discourse, can be formulated using one of the themes within political ecology, namely the "environmental subject" (Robbins, 2012). Broadly speaking, the topics of environmental subject explore "the way that people's behaviours and livelihoods (their actions) within ecologies influence what they think about the environment (their ideas), which in turn influences who they think they are (their identities)" (Robbins, 2012, p. 216). There is only one space and one world that all people are dwelling in, but the way of engaging with the world is never fixed and singular. Working in a poststructuralist direction, Agarwal (2005) suggests that, although practices are always situated in the context of a construct of expectations and obligation and political relations, "to point to the situatedness of practices and beliefs is not to grant social context a deterministic influence on practice and subjectivity. Rather, it is to ground the relationship among structure, practice, and subjectivity on evidence and investigative possibilities" (p. 172). Such an interpretation opens up the endless circle of the producing and the produced. Robbins (2012) suggests that engaging with theories of subject is crucial for a better understanding of how certain environmental actions and identities fit together as the products of power. In the process of production, "the subject" often becomes a vague entity, for there is never a point at which we can regard "the subject" as a fixed status; rather, it is always in the process of formation. Fletcher (2014, pp. 61-62) implies that Foucault's theories on subjectivation (Foucault, 1983) may be read in a dialectical way: the internalized subjectivity can be exercised and transformed into a set of future subjectivities that either consent to or diverge from the formal "pre-existing subjectivity."

To better understand and articulate this process, I will examine the narratives from my informants in relation to recent discussion of the notion of "the Green Tibetan." Originally emerging in the 1980s (Huber, 1997, 2001), "the Green Tibetan" re-emerged in the late 1990s and early 2000s as a "a rapid mobilization of international and domestic environmentalists and transnational investors is accompanied by intensive Chinese and foreign scholarship, media coverage, and explosive growth in tourism" in northwest Yunnan (Coggins \& Zeren, 2014, p. 211; Litzinger, 2004; Moseley \& Mullen, 2014; Yeh, 2014). In short, "the Green Tibetan" is a set of representations in which Tibetans are perceived as 
resourceful in their ecological knowledge and their harmonious ways of living with nature (Huber, 1997). However, the recent trend of using the term addresses more the connection between environmental awareness and the local Tibetan ethnic identity.

Some methodological notes should be made here. Although the bulk of my ethnographic fieldwork was conducted between April and October 2013, other field trips both before and after have also contributed to my understanding of the context of tourism development in Shangri-La and Niru Village. Pursuing ethnographic research in Niru Village, engaging with people and their environment, meant I had to situate myself, and others, in a culturally, socially and politically constructed setting. However, situating does not mean the ethnography is framed within a particular period of time or location. Keeping in mind the ever-present ethical dilemmas, the ethnography started even before I was physically in Shangri-La and Niru Village, and continued to demand my attention and devotion well after I had physically left these places. My belief that human experiences and meaning-making are rooted in people's interpretations, activities and interactions involving themselves and others has resulted in the intersubjective nature of this study. In Niru Village I was a "Jia", which means outsider, visitor, tourist and ethnic Han all at once. In order to make myself familiar to my informants I lived with a local family, engaged in daily chores, and worked with them in the fields. This familiarity eventually helped me gain access to other families/individuals in Niru Village. Once I was more familiar with the villagers, I was able to openly engage in participant observation and interviews.

\section{Tourism encounters in Niru village}

After the series of natural disasters mentioned above, and due to overexploitation, the central government started adopting tourism as a way to turn the economy green. Starting in the late 1990s, the ecotourism development gained increasing support and investment from the state, as well as from international environmental organizations, often working closely with nature reserves and later through a new model of national parks (Zhang, 2013). The idea of tourism as a sustainable alternative economic activity has now been transformed into the everyday discourse of Shangri-La's tourism development (Zhang, 2016a). In Niru Village, the changing ways of utilizing natural resources, and the pending worries and concerns about the natural environment, continue to shape the villagers' daily discussion topics and practices. For example, unusual natural events are often mentioned to express their worries, and nearby mining constructions have always been a concern because of their negative impacts on the environment. As noted in the notion of "the Green Tibetan", local villagers in Niru Village have closely coexisted with nonhuman beings for generations and the local religion, Bon, still spiritually influences their ideas of "nature"; thus, disturbing nature is both spiritually and physically unacceptable. However, as Woodhouse et al. (2015) suggest, there is a more complex picture available concerning the potential collaboration between local geopiety and environmental protection, and "local people should be able to negotiate and engage in the terms for conservation and natural resource management themselves" (p. 305). Below are three sets of events, narratives and scenarios of tourism encounters around Niru Village. Through retelling these narratives, and reading them alongside the notion of "the Green Tibetan", I attempt to shed light on how tourism can be a productive space for the villagers to represent and remake their environmental subjectivities and, consequently, contribute back to the environmental discourse.

\section{The checkpoint}

My first visit to Niru Village was with Wu, a key informant in my fieldwork in Pudacuo National Park and later my host in Niru Village. After several hours traveling on the road, Wu stopped his minivan in front of a checkpoint, made from a spruce trunk. A tent was set up beside the checkpoint and two villagers came out, smiling and talking to $\mathrm{Wu}$ in Tibetan. Following $\mathrm{Wu}$, I stepped out of the minivan. The two villagers nodded at me and asked Wu who I was. Wu said "Jia!" to his village fellows. As we entered the tent, Wu pointed at the spruce trunk and explained to me: 
This is the protection checkpoint we set up ourselves. Because in Niru we still have so many endangered species, like animals, plants and medicinal vegetation, there are many people from outside who come in for poaching and illegal logging. So we set up this tent to scan every vehicle coming and going, every day, day and night. Every household sends one person, and three people take turns staying here for three days. We've done this for many years. The villagers had a meeting to discuss the system and voted to pass it. It's all voluntary.

I listened, and was intrigued. Inside the tent it was dark and simple, with a small fire and some sleeping mats lying around. I asked if they really did this every day. Wu replied quickly "Of course! Those thieves have stolen too much from us so we had to do something. Ever since we built this checkpoint the poaching is much less." I nodded. At this point, he asked me meaningfully:

What do you think of this? Shouldn't you say that we have very good environmental awareness?

Pondering the purpose of his questions, I responded with positivity, "Yes! It's very good, very pioneering, and very strong environmental awareness!" Wu seemed satisfied, but still wore a bitter smile on his face, saying:

It won't last very long if there's no further development.

At first glance, Wu presented a voluntary and genuine stewardship of villagers regarding their "nature", just like the "Green Tibetan" notion would suggest. But the Tibetan Buddhism explanation is absent. In 2000, the Natural Forest Conservation Program was launched, as a 10-year programme to completely ban logging across 41.8 million hectares of natural forest, including the area where Niru Village is located. The villagers are allowed to take only limited amount of wood for their own house building, but are still allowed to harvest mushrooms and herbs in the forest (those which are economically valuable). Thus, from a localism logic, it is understandable that they want to guard the natural resources.

However, more layers are added by Wu's questions about environmental awareness and his comment that it would not last long, especially when put in the context of sustainable development. From what Wu presented, the natural resources in Niru Village's territory need to be guarded for their potential economic value; but based on what measurement? Having worked in Pudacuo National Park for many years, and interacted with many tourists from big cities, Wu is very familiar with the modern concept of conservation and its combination with ecotourism. Thus, it is very likely that it has become part of his perception that nature can be utilized not only as raw materials but also as aesthetic entities. Wu's concern for no further development involved the low number of tourists coming to Niru Village. Having "environmental awareness", in his opinion, must be attractive to me as a tourist. When he subtly lamented that the self-organized conservation would not last long, he was actually expressing a will to realize the economic value of the natural resources through ecotourism. In this context, "the Green Tibetan" is presented as the conventional/normative environmentalist thinking. And, later, after talking more with the villagers about the checkpoint, I realized many of them, especially young people, do not share the wish to "do something with the natural resources." For example, I heard comments like:

When it was bad (outsiders' poaching) before, it was necessary to do something. Now that it's gotten better it's kind of a waste of time to do it. ... better to use our time and energy to do something else.

These are doubts as to the necessity of guarding their forests and resources. But what is this "something else" that is more valuable? Many suggested it would be tourism. And when I posed the question "What is a good life for you?" to many villagers in different circumstances, one of the answers I heard many times was:

City people want to come here, and we want to go to the city.

Here, they are referring directly to tourists from big cities. Although only a few hundred tourists come to Niru Village every year, the Niru villagers want to be more engaged with tourism and to generate new ways of expressing themselves. Not only are they saying "what they want"; they are also 
juxtaposing this with "what other people want." The juxtaposition of "city people" and "we" creates a contrast, a tension and eventually an irony. The irony between city people and the villagers is reflected in the acute awareness of the villagers regarding the great paradox in ecotourism - that one person's desire to escape the urban reality is used to fulfil another's desire to obtain an urban lifestyle.

Yet, there is still a negotiation process between modern and Indigenous ideas of "nature". Later, it became clear that Wu holds an important position in the religious and spiritual practices in Niru Village. However, when the checkpoint episode happened I was merely a tourist and a visitor to the village, and Wu did not talk about the spiritual connections between the villagers and "nature". Rather, he chose to communicate in terms he assumed would be more familiar to me - talking about "environmental awareness", "ecological village" and so on. For him, "nature" is spiritual, economic, and social all at once; therefore, his subjectivities are much richer than what "the Green Tibetan" alone would represent. He is perhaps proud of his culture, but somehow feels shame at the lack of development in Niru Village. His beliefs, knowledge, experiences and assumptions regarding others' perceptions of "nature" were interrelated and displayed through his encounter with me, a tourist.

Against the background of the Anthropocene, environmental activism seems to be more logical than ever. However, the story of the checkpoint shows that different views may exist at the local level. In contrast to the protests in the Qinghai-Tibetan Plateau (Liu, 2012), reported in chinadialogue, whereby local residents refused to have tourism development on their sacred lake, Niru villagers look forward to a new method in order to upgrade their quality of life, possibly engaging with the "integration of Indigenous knowledge and conservation", or "the Green Tibetan."

\section{"Constructing beauty"}

If the story of the checkpoint reflects a process of negotiating and expressing ideas about "nature" (or values of nature) between Wu as a host and me as a tourist, my conversations with Uncle Denzeng in Niru Village present another understanding of this process, but among the villagers. Operating a family tourism business with his son and daughter-in-law, Uncle Denzeng was one of the first people in Niru Village to start developing tourism, as he describes:

\footnotetext{
Many tourists came in 2002 and 2003. There was nowhere for them to live back then, so we arranged for them to camp in the schoolyard. I was still working in town, but I already knew I wanted to do this (tourism)... The most important thing is to protect the environment (because) that's what tourists want to see. But every time I talked about environmental issues at village meetings, people were upset and against me. They said, "We have to fetch firewood, build houses, feed cows!" I told them that protecting nature is good for them. But they didn't understand it. They cannot think. They don't have scientific knowledge.
}

Again, the environmental protection Uncle Denzeng advocated here can be interpreted as what "the Green Tibetan" entails, but here he openly criticized other Tibetan villagers and regarded them as backward. Knowing that many of the practices he criticized were in fact carried out in a sustainable manner before the 1950s, when the logging industry changed people's ways of living, I nevertheless asked Uncle Denzeng if there was an element of tradition at play there. He asserted that it should nevertheless not be excused, and that it was the village cadres who were to blame. According to him, none of the cadres were creative and innovative enough to lead the villagers to a better life. "What is a better life?" I asked him. He answered:

\footnotetext{
A better life is to follow what the central government requires, for example, now there's a national project to promote "Beautiful China (měilìzhōngguó)" and "Beautify Villages (měilixiāngcūn)." First, it has to be beautiful people. But people here can never be beautiful. So what can we do? We have to make nature beautiful. We need to do a lot of things to do that. Replanting those trees that were cut before, and not littering, etc. ... we have to construct beauty (zàoměi). Otherwise, people come here and they've read on the Internet that Niru is "Heaven on Earth, the last paradise, the real Shangri-La" and then they see that the reality is like this - dusty, ugly and empty... In the winter, the whole village is grey and dusty. I've heard many tourists say that the reality was different from what they expected, and this is ridiculous.
} 
It is obvious here that Uncle Denzeng was influenced by the official regime of romanticizing rural areas, as well as believing he knew tourists' views on what Niru Village should be like. This led to his emphasis of the phrase "construct beauty", particularly when related to "natural beauty." As a localborn Tibetan, Uncle Denzeng went to work in town at a young age and came home after he had retired. He seemed to have rather negative opinions of his fellow villagers regarding how they handle "nature", and the "traditional way of living", and felt the self-contented lifestyle is backward. Viewing traditional resource management as constraining people in the position of being regulated, Uncle Denzeng advocated a more active position entailing the villagers regulating their own environment. As an innovator in the village, he tried to appropriate not only his own home environment but also the village's surroundings. For instance, he made road signs to direct tourists to the right trek to a lake, on which he signed "made by Denzeng". He believed that improving the facilities is fundamental for ensuring that tourists are satisfied and that exploring the beauty of "nature" will, in turn, help the village become a better place and help the villagers have a better life.

However, other villagers expressed rather different views on Uncle Denzeng's business, which today attracts nearly a thousand tourists per year. The villagers claimed that local rubbish had been discarded by Uncle Denzeng's tourists rather than by them. One villager stated: "And they talk loudly and shout when they go to our sacred sites." "That's absolutely forbidden, the gods will be angry and our crops will grow poorly!" Interestingly, these villagers were also using the "nature" argument to negotiate what tourism should be like. For these villagers, tourists are welcome but must follow certain rules. We can thus see "the Green Tibetan" operating here as well, with an emphasis on the "Tibetan" part. The villagers' complaints also revealed that it was Uncle Denzeng's attitude that was the most provocative to them, as he spoke as if he knew best. Uncle Denzeng was not the only one trying to develop tourism entrepreneurship, but he was not approved of because he differentiated himself from the other villagers, portraying himself as "cultivated" and "modern" and the others as "uneducated" and "premodern". The other villagers also took offence at his appropriating the environment and turning it into what tourists wanted to perceive and experience. In other words, Uncle Denzeng was trying to "modernize" and "ecologize" the village into a metropolitan tourist's product for so-called green consumption, and the villagers' narratives in fact indicate a willingness to negotiate and take part in the place-making process.

It is useful to pause here for a moment; when Uncle Denzeng talked about "making beauty" and "constructing nature", was he acting as the agent that was going to construct nature, or had he been enticed by the subject position of "constructing nature"? Like Wu, Uncle Denzeng promoted the idea of ecotourism, but unlike Wu's ambiguous position between traditional and modern, Uncle Denzeng was explicit in expressing his willingness to change the villagers' current livelihoods, even the human-nature relationship in the traditional sense.

Uncle Denzeng's story is informative, and shows that within a seemingly self-regulated community dramatically different opinions can be generated. While Uncle Denzeng is aware of the external "reality" - that tourists desire a remote and pure "nature" experience - the villagers seem to have difficulty taking in the whole package of ecotourism, which entails some ideas implying that their way of life is backward and primitive. Also, it shows that through the process of negotiating with other villagers, Uncle Denzeng identifies more with the "scientific" way of relating to nature. When asked about the local deities residing in the mountains and rivers, he said "if throwing rubbish in the mountains didn't give them (the villagers) bad luck, perhaps there's no god then", at once rationalizing and deconstructing their beliefs. The story of Uncle Denzeng presents us with a complicated process of translating environmental discourse into local contexts, and identifies the tensions involved in this process.

\section{Niru village, the real Shangri-La}

During my stay in Niru Village I talked with a small number of tourists, and majority of them mentioned "the real Shangri-La." Some of the tourists who come to Shangri-La are disappointed at the 
"inauthentic" tourism experiences in the centre of town, where activities are commercially packaged and staged, and thus search elsewhere for "the real Shangri-La." Others, who had heard of or experienced the commercialization in Shangri-La and were thus searching for "the real Shangri-La", found Yading, a nearby village on the border of Sichuan Province and Yunnan Province. Yading Village is home to three holy Snow Mountains. Visitors have to cross several mountains to get there, and Niru is normally the starting point. In Niru Village I met a tourist from Guangzhou City, one of the biggest cities in China. He said:

Actually I'd heard of Niru before I came to Shangri-La. I knew you could go to Yading by mountain treks, and to do that you have to start from Niru. I wasn't interested in touristic activities in Shangri-La. The real Shangri-La is in less exploited areas, for example Niru or Yading.

Interestingly, Niru has become known for both the inauthentic experiences in official "ShangriLa" as well as the imagined authentic experience in "the real Shangri-La." Since Yading has been imagined and promoted as "the real Shangri-La", after the renaming of Zhongdian, it has experienced growing visitation from international and domestic tourists. It is recorded elsewhere that villagers in Yading have considerably changed their lifestyle (Guo, 2012). It now seems that Niru is becoming another alternative to Yading; villagers know that city people appreciate Niru's beauty and charm, and are also highly aware of the air pollution and lack of natural aesthetics in the big cities, making tourists flee to places like Niru. I often heard villagers imitate tourists' exclamations, such as "I wish I could live here forever!" and "Let me die here drunk!" The villagers, on the one hand, find such expressions ridiculous. On the other hand, they understand tourists as having great demands as well as generating tremendous value from the very "being" of the village. Learning that I was going to stay in Niru Village for three months, a young villager commented:

That's insane. I can't stand to be here even one more day. But I know you people are here to enjoy your leisure time, right? Many tourists come here for that. They do nothing, just sleep and stare into the air!

The sense of boredom expressed above needs to be read in context. Here, the young villager tried to make sense of the city tourists who would come all the way to Niru and "do nothing". For him it is at the same time both a peculiar idea and novel, perhaps even resembling modernity. I have also observed other villagers, very often young ones, copying tourists' ways of dressing, and sometimes also their ideas of traveling. One day, after having been in the village for about two months, I asked the younger son in my host family if I could accompany him to the family's pasture up in the mountains. He agreed. The next day he asked to borrow my $50 \mathrm{~L}$ backpack and filled it with snacks, Coca Cola and other mountaineer gear he had collected. Carrying my backpack and holding a walking stick he had gotten from an American tourist who had stayed in the family house, he looked like a mountaineer. Smiling, and posing to my camera, he joked, "I'm a tourist!"

My friend's temporarily enacting the performance of "the tourist" is more than mimicry; it also shows the process of his forming an identity through othering himself from his own local social context. This does not mean he feels he belongs in city life but rather, as he later expressed, that he feels pulled in different directions:

Every time I get to town I feel tired after just a short while. There's nothing I can do there in town. I prefer to be in the mountains. I can stay up in the mountains several days. In the mountains I feel free. But whenever my friends ask me if I want to go to town, I can't resist.

In this reflective way, he expressed his sense of belonging to the mountains, as opposed to the city. But his performance of a hiker exposes another layer of his subjectivities - that to fully express his sense of belonging he sometimes needs to become someone else (the tourist). However, this is not to say he is simply influenced by another culture, but rather that his awareness of the contrast between city and village life enables him to represent himself in a different way. The way the villagers express themselves also influences outsiders, who sometimes hold stereotypical views on things. 
Another young woman, who had studied in Shangri-La for several years and returned to Niru Village in 2012, said:

Life is different in the city. Many people asked me if I could get used to the village life again. The first year (after I came back) was a bit hard. But now I'm totally used to life in the village. I even think it's quite good. We grow our own vegetables and grains, and feed our own animals. We have a house and live with our families. We live close to the holy mountains. I feel pretty happy here.

This woman and my friend both seem to be connected to the local environment in an emotional way, perhaps mirroring the Western image of sublime nature as well as the ecological thinking within Tibetan Buddhism. Esler (2016) observes that some Tibetans have internalized the image that Tibetan Buddhism and the traditional lifestyle in Tibetan areas are superstitious and backward; however, the recent promotion of Tibetan geopiety in environmental protection (such as in the rise of "the Green Tibetan") has made more Tibetans feel a sense of a superiority of their culture. I would add here that new environmental subjectivities are constantly in the making, and that the sense of belonging or pride can come from a mix of ideas, just as Yeh (2014b) suggests: "The Green Tibetan was...not merely a top-down imposition by transnational conservation organization; rather, it was forged out of the production of local and translocal Tibetan interests and identities arising out of radically different frameworks and communities" (p. 265).

Furthermore, the young woman's narrative above shows that the formation of new environmental subjectivities is a two-way process: after experiencing different environments and the interaction and exchange between radically different frameworks, she needs to find a new position in life for herself. Her feeling happy after going through a period of hard times reflects her adoption of a new understanding of herself and of her relationship with the environment. Although her reaction is the opposite of that of the other villager, who complained about the boring life in the village, the girl's representation of a good lifestyle in the village similarly presents how she internalized and made use of the imaginaries of the "ecological life" city people dream about. Meanwhile, these new understandings cast new influences and contributions back to the externally generated representations of the environment; as she talked to me, her multifaceted subjectivities challenged the earlier statement that "city people want to come here and we want to go to the city", which again indicates the complexity and dynamic nature of subject formation.

The process of subject formation and embodiment of the local residents in Niru Village in response to "the Green Tibetan" is similar to the "translocal assemblage" Kumar (2014) theorizes. This author describes how each of the different actors involved in protecting Niyamgiri holds diverse ideologies, beliefs and priorities and, through choosing the aspects which fit their own ideologies and contexts, transform each other and further develop each other's positions (Kumar, 2014). Lockwood and Davidson (2010) also employ the theory of assemblage to describe how Australian natural resource governance is a hybrid of three mentalities of government, namely neoliberalism, localism and ecocentrism. The inevitable overlaps into each other's domains may cause conflicts and tensions, but also provide opportunities for creating further emergent assemblages; an act which then allows institutional and discursive spaces to be inserted into and used for intervening in different situations.

\section{Discussion and conclusion}

Moore (2015) criticizes the use of the notion of Anthropocene to generalize humanity as a homogeneous acting unit, and suggests that the new epoch instead be named Capitalocene, as the capitalist way of dealing with nature has had more impact on the Earth than any set of actions has. Moore (2017) also stresses that the starting date of capitalism should be the beginning of the era of Columbus (1450), in order to include capitalism's early-modern origins, in which the first signs of landscape transformation can be seen. However, while discussions on terminology are perhaps useful in regard to what has happened in the past, they may not be as important concerning what will happen in the future. Our current goal is to recognize what we have been living with now and will live with in the 
future. Such a goal may allow us to see that, due to the precarity we all live in and the collaborations we all need for survival, capitalistic and alternative ways of dealing with nature are interdependent on each other now more than ever before. As the discourses of environmental crisis, global environmental change and, overall, the Anthropocene, permeate all corners of our lives, it is easy, by way of remedy, to construct and essentialize a fixed Other. In the situation studied here, this fixed Other is tourism, or "the Green Tibetan." What we often forget is the space between the one and the Other, where conflicts as well as positive possibilities may arise.

While the tourism development in Shangri-La can be seen as a result of organizing nature, it is also an important medium through which to challenge the essentialized idea of nature/culture, and can provide a space through which the villagers are able to present their environmental subjectivities as multilayered and ever-changing. As the basic ideas within ecotourism are to combine nature conservation and community-based development, brought together through a more general tourism industry sector ecotourism is often used as a substitute to replace other staple, and stable, economies ("Cheap Nature", in Moore's (2015) terms), especially when the cost of the staple economies is no longer cheap and they are increasingly destructive. However, neither conservation nor ecotourism can escape from the capitalist logic of utilizing "nature". Instead, both emerge from the reduction of the ecological surplus and, at the same time, still remain part of the capitalist system and thus continue to contribute to the same exploitation of natural resources. Yet, as this paper has shown, all is not clear. The exploration of what happens when individuals who have different environmental subjectivities but are still enmeshed within tourism is still open and evolving. Producing compelling readings of these encounters is challenging, but is also likely to be productive.

It is thus important to look at these encounters from new perspectives. Tsing (2015) proposes the notion of contaminated diversity for how we might move forward in our thinking and doing, as we face the global state of precarity: "We are contaminated by our encounters; they change who we are as we make way for others... Everyone carries a history of contamination, purity is not an option" (p. 27). Recently, in a tourism context, Tucker (2017) suggests that we, too, should reflect on the phenomenon of encounter-as-contamination, in order to recognize the open-endedness of indeterminate encounters in tourism. In this article I have tried to show some of these embodied encounters of different environmental subjectivities and the new meanings emerging from these encounters. Similar to the process of contamination leading to diversity and collaboration, these encounters play important roles for the constitution of future environmental subjects, through tourism.

In Niru Village, discussions relating to "nature" were often buried beneath other verbal exchanges about daily chores and were clearly formulated only in limited contexts, with tourism acknowledged as one of these day-to-day contexts. In relation to "nature", the tourism encounters in Niru Village present us with a complex and diverse process whereby the local villagers try to translate, appropriate and negotiate the broader discourse of environment into their own ideas, actions and identities, which is a process of (re)producing environmental subjectivities. In order to understand this process, the recent notion of "the Green Tibetan" was read alongside my informants' narratives. The villagers' narratives illuminate different ways of negotiating the notion of "the Green Tibetan" with their own previously existing and available subjectivities. While they were aware of this projection and its potential benefits for the local economy, the villagers also actively took part in the projection through their encounters with tourists as well as with their fellow villagers. What is happening in Niru Village thus responds to the question posed at the beginning, regarding how the concept of Anthropocene can help us make sense of the Earth through tourism (Gren \& Huijbens, 2016). Although the grand idea of the Anthropocene, in the local context, appears only to be vaguely manifest through people's concerns over degrading nature, through tourism encounters the villagers may become more aware of what is going on and make local-global connections of environmental changes.

To conclude, I suggest that the Anthropocene is best considered within the broader environmental discourses, of which sociocultural justice is also a part. While the most dramatically changing environments are in the areas where the poorest populations live, the inhabitants do not always hold the same ideas about sustainable development. However, tourism development does make villagers in 
even a remote village in Southwest China aware of conservation, and thus provides social space for them to negotiate these terms for their own interests. Furthermore, different local contexts can provide more detailed and diversified examples of how the embodied encounters are enabled through tourism, and allow us to better understand an inevitable process of negotiation and appropriation. The political ecology approach will continue to be a useful tool for assisting the analysis in situated contexts, while we should also note that even in places in the so-called developed (or "First") world, environmental and social transformations are happening and are affecting individuals in similar ways as in less developed areas. Therefore, the intersecting field of ecotourism, environmental subjectivities and metanarratives emerging from environmental discourses (such as that of the Anthropocene) can be a fruitful arena for future studies.

\section{Acknowledgement}

I would like to than three reviewers for their insightful feedbacks and suggestions. Thanks also go to the research participants in Niru Village who took part in the fieldwork.

\section{Disclosure statement}

No potential conflict of interest was reported by the author.

\section{Funding}

This work was supported by the Swedish Research Council Formas under Grant "Mobilizing the rural: Post-productivism and the new economy [Grant Number: 2011-9018-18821-43]."

\section{Notes on contributor}

Jundan Zhang is a post-doc researcher within the Department of Geography and Economic History at Umea University, Sweden. Her current research focuses on relationships between environmental discourses and environmental subjectivities in the context of tourism in peripheral areas, in particular how individuals translate and appropriate broad ideas on "nature" into their exchanges with other human and non-human actors through tourism activities, and how these translations and appropriations in turn contribute to the discourses of environment.

\section{References}

Agrawal, A. (2005). Environmentality: Community, intimate government, and the making of environmental subjects in Kumaon, India. Current Anthropology, 46(2), 161-190. doi:10.1086/427122

Baruchello, G. (2016). Good versus bad tourism: Homo viator's responsibility in light of life-value onto-axiology. In M. Gren \& E. H. Huijbens (Eds.), Tourism and the Anthropocene (pp. 111-128). London: Routledge.

Castree, N. (2014a). The Anthropocene and geography I: The back story. Geography Compass, 8(7), 436-449. doi:10.1111/ gec3.12141

Castree, N. (2014b). Geography and the Anthropocene II: Current contributions. Geography Compass, 8(7), $450-463$. doi:10.1111/gec 3.12140

Castree, N. (2014c). The Anthropocene and geography III: Future directions. Geography Compass, 8(7), 464-476. doi:10.1111/gec3.12139

Coggins, C., \& Zeren, G. (2014). Animate landscapes: Nature conservation and the production of agropastoral sacred space in Shangrila. In E. Yeh \& C. Coggins (Eds.), Mapping Shangrila: Nature, personhood, and sovereignty in the SinoTibetan borderlands (pp. 205-228). Seattle: University of Washington Press.

Compilation Committee of Luoji Township Annals. (2007). Luoji township annals. Luoji: Luoji Township Government.

Crutzen, P. (2002). Geology of mankind. Nature, 415, 23.

Crutzen, P., \& Stoermer, E. F. (2000). The Anthropocene. Global Change Newsletter, 41, 17-18.

Davies, J. (2016). The birth of the Anthropocene. Oakland: University of California Press.

Eijgelaar, E., Amelung, B., \& Peeters, P. (2016). Keeping tourism's future within a climatically safe operating space. In M. Gren \& E. H. Huijbens (Eds.), Tourism and the Anthropocene (pp. 17-33). London: Routledge. 
Esler, J. (2016). 'Green Tibetans' in China: Tibetan geopiety and environmental protection in a multilayered Tibetan landscape. Asian Ethnicity, 18 (3), 1-12. doi:10.1080/14631369.2015.1090367

Fletcher, R. (2014). Romancing the wild: Cultural dimensions of ecotourism. Durham: Duke University Press.

Foucault, M. (1983). The subject and power. In H. Dreyfus \& P. Rabinow (Eds.), Michel Foucault: Beyond structuralism and hermeneutics (pp.208-264). Chicago: University of Chicago Press.

Gren, M., \& Huijbens, E. H. (2014). Tourism and the Anthropocene. Scandinavian Journal of Hospitality and Tourism, 14 (1), 1-17. doi:10.1080/15022250.2014.886100

Gren, M., \& Huijbens, E. H. (Eds.). (2016). Tourism and the Anthropocene. Abingdon: Routledge.

Grumbine, R. E., \& Xu, J. (2011). Creating a 'conservation with Chinese characteristics'. Biological Conservation, 144, 1347-1355. doi:10.1016/j.biocon.2011.03.006

Guo, J. (2012). Xue Shan Zhi Shu [Tales of Kha ba dkar po]. Kunming,Yunnan: Yunnan Renmin Chubanshe [Yunnan People Press].

Hall, C. M. (2016). Loving nature to death: Tourism consumption, biodiversity loss and the Anthropocene. In M. Gren \& E. H. Huijbens (Eds.), Tourism and the Anthropocene (pp. 52-74). London: Routledge.

Haraway, D. (2015). Anthropocene, capitalocene, plantationocene, chthulucene: making Kin. Environmental Humanities, 6 , 159-165.

Hillman, B. (2003). Paradise under construction: Minorities, myths and modernity in Northwest Yunnan. Asian Ethnicity, 4(2), 175-188.

Huber, T. (1997). Green Tibetans: A brief social history. In F. Korom (Ed.), Tibetan culture in the Diaspora (pp. 103-119). Vienna: Verlad der Österreichischen Akademie der Wissenschaften.

Huber, T. (2001). Shangri-La in exile: Representations of Tibetan identity and transnational culture. In T. Dodin \& H. Räther (Eds.), Imagining Tibet: Perceptions, projections, and fantasies (pp. 357-371). Somerville, PA: Wisdom Publications.

Huijbens, E. H., \& Gren, M. (2016). Tourism and the Anthropocene: An urgent and emerging encounter. In M. Gren \& E. H. Huijbens (Eds.), Tourism and the Anthropocene (pp. 1-14). London: Routledge.

Jóhannesson, G. T., Ren, C., \& Van Der Duim, R. (2016). ANT, tourism and situated globality: Looking down in the Anthropocene. In M. Gren \& E. H. Huijbens (Eds.), Tourism and the Anthropocene (pp. 77-93). London: Routledge.

Jönsson, E. (2016). Anthropocene ambiguities: Upscale golf, analytical abstractions, and the particularities of environmental transformation. In M. Gren \& E. H. Huijbens (Eds.), Tourism and the Anthropocene (pp. 152-170). London: Routledge.

Kolås, $\AA$ (2008). Tourism and Tibetan culture in transition: A place called Shangrila. New York: Routledge.

Kristoffersen, B., Norum, R., \& Kramvig, B. (2016). Arctic whale watching and Anthropocene ethics. In M. Gren \& E. H. Huijbens (Eds.), Tourism and the anthropocene (pp. 94-110). London: Routledge.

Kumar, K. (2014). The sacred mountain: Confronting global capital at Niyamgiri. Geoforum, 54, 196-206, doi:10.1016/j. geoforum.2013.11.008.

Law, A., De Lacy, T., Lipman, G., \& Jiang, M. (2016). Transitioning to a green economy: The case of tourism in Bali, Indonesia. Journal of Cleaner Production, 111, 295-305.

Litzinger, R. (2004). The mobilization of "nature": Perspectives from north-west Yunnan. The China Quarterly, 178, 488-504.

Liu, J. (2012). Tibetans fight tourism on holy lakes. Retrieved from https://www.chinadialogue.net/article/show/single/en/ 5114-Tibetans-fight-tourism-on-holy-lakes, Accessed on 27 March, 2015.

Lockwood, M., \& Davidson, J. (2010). Environmental governance and the hybrid regime of Australian natural resource management. Geoforum, 41(3), 388-398, doi:10.1016/j.geoforum.2009.12.001.

Lu, Y. (2005). Meili Nizu: Laizi Xianggelila Zangzu Shengtai Wenhua Cun de Baodao 鬼未力尼汝: 来自香格里拉藏族生态文化 村的报道 [Beautiful Niru: Report from a Tibetan Eco-cultural Village in Shangri-La]. Beijing: The Ethnic Publishing House.

Moore, A. (2015). Tourism in the Anthropocene Park? New analytic possibilities. International Journal of Tourism Anthropology, 4(2), 186. doi:10.1504/IJTA.2015.070067

Moore, J. W. (2015). Capitalism in the web of life: Ecology and the accumulation of capital (1st ed.). New York, NY: Verso.

Moore, J. W. (2017). The capitalocene, part I: On the nature and origins of our ecological crisis. The Journal of Peasant Studies, 44(3), 594-630, doi:10.1080/03066150.2016.1235036

Moseley, R. K., \& Mullen, R. B. (2014). The nature conservancy in Shangri-La: Transnational conservation and its critiques. In E. T. Yeh \& C. Coggins (Eds.), Mapping Shangri-La: Contested landscapes in the Sino-Tibetan Borderlands (pp. 129152). Seatle: University of Washington Press.

Mostafanezhad, M., Norum, R., Shelton, E., \& Thompson-Carr, A. (Eds.). (2016). Political ecology of tourism: Community, power and the environment. London: Routledge.

Mu, B., Yang, L., \& Zhou, M. (2007). The progress of eco-tourism researches of nature reserves in China. Journal of Fujian Forest Science and Technology, 34(4), 241-247.

Nepal, S., \& Saarinen, J. (2016). Political ecology and tourism. London: Routledge.

Purdy, J. (2015). After nature: A politics for The Anthropocene. Cambridge, MA: Harvard University Press.

Reddy, M. V., \& Wilkes, K. (2015). Tourism in the green economy. London: Routledge. 
Robbins, P. (2012). Political ecology: A critical introduction. Chichester, MA: Wiley.

Stonich, S. C. (1998). Political ecology of tourism. Annals of Tourism Research, 25(1), 25-54. doi:10.1016/S0160-7383(97) 00037-6

Svensson, D., Sörlin, S., \& Wormbs, N. (2016). The movement heritage: Scale, place, and pathscapes in Anthropocene tourism. In M. Gren \& E. H. Huijbens (Eds.), Tourism and the Anthropocene (pp. 131-151). London: Routledge.

Tsing, A. L. (2015). The mushroom at the end of the world: On the possibility of life in capitalist ruins. Princeton: Princeton University Press.

Tucker, H. (2017). Contaminated tourism: On pissed off-ness, passion and hope. Paper presented at the Critical tourism studies VII conference, 25-29 June, Palma de Mallorca, Spain.

Woodhouse, E., Mills, M.A., McGowan, P.J., \& Milmer-Gulland, E.J. (2015). Religious relationships with the environment in a Tibetan rural community: Interactions and contrasts with popular notions of indigenous environmentalism. Human Ecology, 43(2), 295-307.

Xu, H., Cui, Q., Sofield, T., \& Li, F. M. S. (2014). Attaining harmony: Understanding the relationship between ecotourism and protected areas in China. Journal of Sustainable Tourism, 22(8), 1131-1150. doi:10.1080/09669582.2014.902064

Xu, J., Ma, E. T., Tashi, D., Fu, Y., Lu, Z., \& Melick, D. (2005). Integrating sacred knowledge for conservation: Cultures and landscapes in southwest China. Ecology and Society, 10(2), 7. [online]. Retrieved from http://www.ecologyandsociety. org/vol10/iss2/art7/

Yang, S. (2012). Connected with the three rivers: An account of the application process for the three parallel rivers of Yunnan protected area. Kunming: Yunnan People Publishing.

Yeh, E. T. (2014). The rise and fall of the Green Tibetan: Contingent collaborations and the vicissitudes of harmony. In E. T. Yeh \& C. Coggins (Eds.), Mapping Shangri-La: Contested landscapes in the Sino-Tibetan Borderlands (pp. 255-278). Seatle: University of Washington Press.

Zalasiewicz, J., Williams, M., Fortey, R., Smith, A., Barry, T. L., Coe, A. L., ... Stone, Philip (2011). Stratigraphy of the Anthropocene. Philosophical Transactions of the Royal Society A: Mathematical, Physical and Engineering Sciences, 369(1938), 1036-1055. doi:10.1098/rsta.2010.0315

Zhang, J. (2013). Political ecology of tourism worldmaking: A case of Shangri-La County, Southwest China, in J. Sarmento \& E. Brito-Henriques (Eds.), Tourism in the Global South: landscapes, identities and development (pp. 193-207). Lisbon: Center for Geographical Studies.

Zhang, J. (2016a). Political ecology of Shangri-La: A study of environmental discourse, tourism development and environmental subjects (Doctor of Philosophy), University of Otago, Dunedin. Retrieved from http://hdl.handle.net/10523/6361

Zhang, J. (2016b). Political ecology of tourism: Community, power and the environment. In M. Mostafanezhad, R. Norum, E. Shelton, \& A. Thompson-Carr (Eds.), Rethinking ecotourism in environmental discourse in Shangri-La: An antiessentialist political ecology perspective (pp. 151-168). London: Routledge.

Zhang, J., \& Tucker, H. (2018). Knowing subjects in an unknown place: Producing identity through tourism and heritage in Niru Village, Southwest China. In G. Hooper (Ed.), Heritage at the interface: Interpretation and identity (pp. 106-120). Gainesville: University Press of Florida.

Zhao, G., \& Shao, G. (2002). Logging restrictions in China: A turning point for forest sustainability. Journal of Forestry, 100 (4), 34-37.

Zinda, J. A. (2014). Making national parks in Yunnan: Shifts and struggles within the ecological state. In E. Yeh \& C. Coggins (Eds.), Mapping Shangrila: Nature, personhood, and sovereignty in the Sino-Tibetan Borderlands (pp. 105128). Seattle: University of Washington Press. 